\title{
Saville 法によるグルタチオンの比色定量に及活す
} 除蛋白剂の影響に就々で

小川政䕐（椙山女学園大学家政学部食物学教室）

昭和 35 年 3 月 29 日受理

\section{I. 緒言}

最近 Saville(1,2) (1958) はアゾ色素によるシステインの比色定量法を報告して招り，これに要する試薬は次 の如きものである.（I） $0.01 \mathrm{M}$ 亜硝酸曹達の $5 \mathrm{ml}$ を $1 \mathrm{~N}$ 硫酸 $40 \mathrm{ml}$ に加え水にて $100 \mathrm{ml}$ とする. (II) $5 \mathrm{~g}$ のアンモニウムスルファメートを水に溶解して 11 とする. (III) $3.44 \%$ のスルファニルアミドを含む $0.4 \mathrm{~N}$ 塩酸 4 容と, $1 \%$ の塩化第二水銀を含む $0.4 \mathrm{~N}$ 塩酸 1 容との混合液. (IV) $\mathrm{N}-1$ ナフチルエチレンジアミン重塩 酸塩（再結精製する）の $1 \mathrm{~g}$ を $0.4 \mathrm{~N}$ 塩酸 11 亿溶解する（但しIII，IV を混合した時発色してはいけない。 これらは密栓して眝え机ば 2 週間は使用に耐える). 定量時にはシステイン塩酸塩の $0.01 \mathrm{~N}$ 塩酸溶液 $1 \mathrm{ml}$ (シ

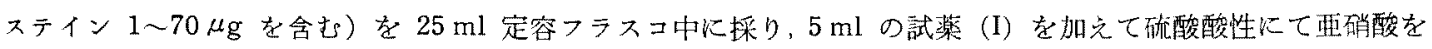
作用せしめて S ニトロソシステインとなし，4〜5 分間後過剩の遊離恶硝酸はアンモニウムスルファィート（試 薬 II) $1 \mathrm{ml}$ を加えて激しく振殟して除き, 更に 1 2 分間後, 予め $\mathrm{Hg}$ と共存せしめたるスルファニルアミ

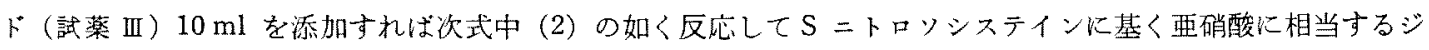
アゾニウム塩を生成し（むし $\mathrm{Hg}$ “を戦独に添加すれば（1）の如くなる）このものは最初に存在するシステイ

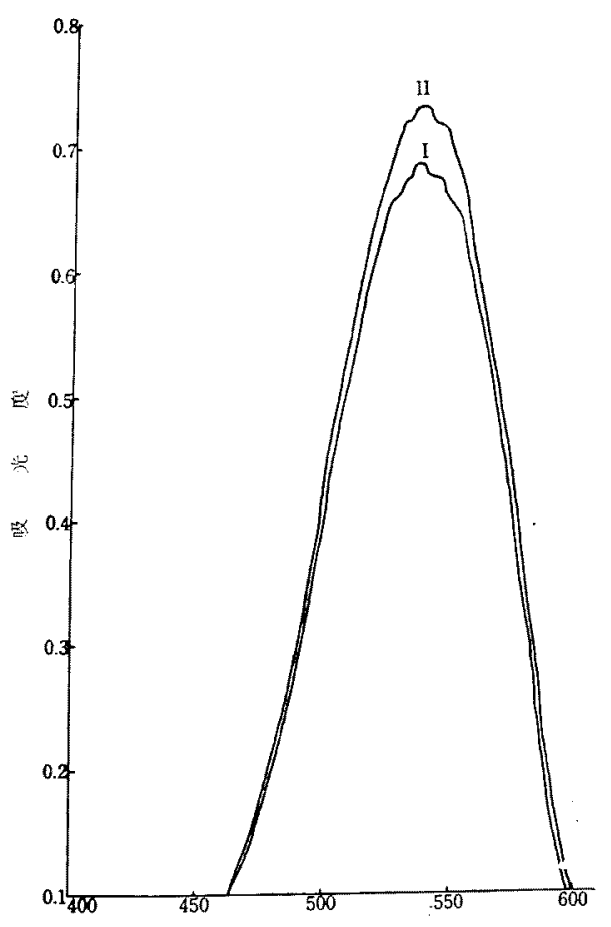

波 $\left[\begin{array}{l}5 \\ \times\end{array}\right.$

第1同グルタチオンとシステインの吸収曲楾 $\mathrm{I}$ : システィン $\mathrm{HCl}\left(4 \times 10^{-4} \mathrm{M}\right) \mathrm{M} / 4 \mathrm{SSA}$ 溶浽 II : GSH $\left(4 \times 10^{-4} \mathrm{M}\right) \mathrm{M} / 4 \mathrm{SSA}$ 浴液 波㩆剩: $1.0 \mathrm{~mm}$ ンに相当する故，N-1ナフキルエチレンジアミン重塩酸塩 (試薬 IV) を加古て $25 \mathrm{ml}$ 標線にまで满せば鮮紅色のアゾ色 素を形成する故、システインを含まさる同栐に処理した対照 溶夜を盲検として 2 分間後光電光度計にて比色して，予得 た標集検量線により試料中のシステイン量を知るものであ る. Saville が示した反応は次の通りである。
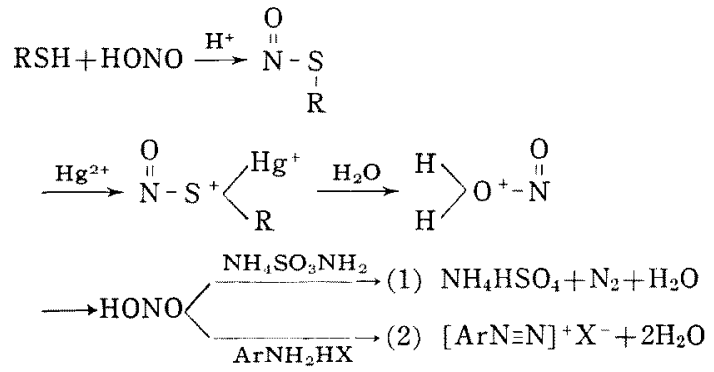

これにより SH 化合物を微量正確 ( $1 \mathrm{ml}$ 中 $30 \mu \mathrm{g}$ のシス テインを含む時の誤差 $\pm 1.0 \%$ ）飞比色定量世られ得るもの である、氏等は組織グルタチオンの定量にも本法の心用はら 九得べき事を述べているが，その具体的方法に就いては言及 していないので予は数種の組䄉浸出除坐白剤にて処理した場 合これが適用の可否を検討した。

従来生物組織上りSH 化合物を漫出する為には葆酸, 三塩

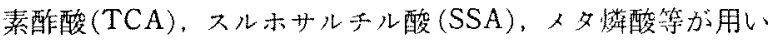

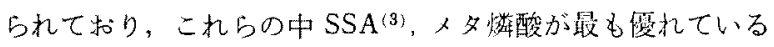

* On the Effect of Some Acid Precipitating Agents, upon the Method of Colorimetric Estimation of Glutathione by Saville.

By Masayoshi OGAWA (Department of Nutrition and Food, Sugiyama Women Senior College, Nagoya) 
といわれるが，次汇述べるように予は葰酸，TCA，SSA 等は何れむ本法に適用可能である事を確めたが, メタ

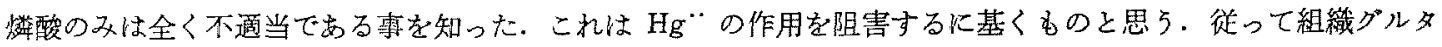
チオンを漫出し本法を適用するにはSSA が最も適切なものと思う。

\section{II. 実験方法並びに結果}

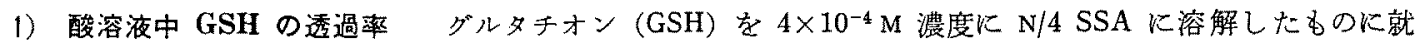

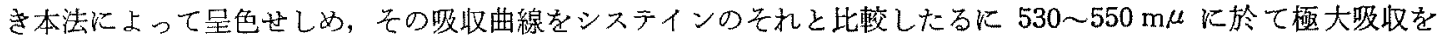
示した（第 1 図). 依て $\mathrm{N} / 4 \mathrm{SSA}, \mathrm{N} / 4 \mathrm{TCA}$ 及び $2 \%$ 苳酸等の溶液中 1 乃至 $6 \times 10^{-4} \mathrm{M} K \mathrm{GSH}$ を溶解した ものに就いて $540 \mathrm{~m} \mu$ に怙计る透過率を梌し次の第 1 表の結果を得た.

片対数紙を用い䋛軸に透過率を横軸に濃度をとればこれが检量線は原点を通る直線を示す，従って SSA， TCA，苳酸等を用いて除蛋白した組織浸出液に就き，本法を道用して GSH の定量が出来る.

第 1 表 酸溶液中 GSH の透過率 $(\%) \quad(540 \mathrm{~m} \mu, 1 \mathrm{~cm}$ cell) GSH のモル数 $\quad 1 \times 10^{-4} 2 \times 10^{-4} 3 \times 10^{-4} 4 \times 10^{-4} 5 \times 10^{-4} 6 \times 10^{-4}$ $\begin{array}{lllllll}1 \mathrm{ml} \text { 中の } \mathrm{GSH}(\mu \mathrm{g}) & 30.70 & 61.40 & 92.10 & 122.8 & 153.5 & 184.2\end{array}$ $\begin{array}{lllllll}\text { GSH (2\% 苳醉) } & 66.50 & 44.50 & 28.25 & 19.25 & 13.50 & 9.50\end{array}$ $\begin{array}{lllllll}\text { GSH (N/4 SSA) } & 66.90 & 45.50 & 28.50 & 19.50 & 14.25 & 9.25\end{array}$ GSH (N/4 TCA) $45.00 \quad 29.50 \quad 13.25$ $\begin{array}{lllllll}\text { GSH }\left(10^{-2} \mathrm{~N} \mathrm{HCl}\right) & 67.50 & 46.40 & 30.50 & 19.25 & 13.75 & 9.00\end{array}$

第 2 表 各種酸溶液の GSH 溶液 $(80 \mu \mathrm{g} / 1 \mathrm{ml})$ の透過寗（\%) と 経時変化 $(540 \mathrm{~m} \mu, 1 \mathrm{~cm}$ cell)

\begin{tabular}{|c|c|c|c|c|c|}
\hline 経過時間数 & $\mathrm{SSA}(\mathrm{N} / 4)$ & $\mathrm{TCA}(\mathrm{N} / 4)$ & 苳酸 $(2 \%)$ & $\mathrm{HCl}\left(10^{-2} \mathrm{~N}\right)$ & $\mathrm{HPO}_{3}(2 \%)$ \\
\hline 10 分 間 & 35.0 & 34.5 & 35.0 & 35.0 & 44.2 \\
\hline 30 & 35,0 & 34.5 & 35.0 & 35.0 & 51.5 \\
\hline 60 & 35.0 & 34.5 & 35.0 & 35.0 & 94.0 \\
\hline 24 間 & 35.0 & 34.5 & 35.0 & 35.0 & \\
\hline
\end{tabular}

第 3 表 試料に添加した既知量 GSH の检出

\begin{tabular}{|c|c|c|c|c|c|}
\hline 試料の種類 & 供試液の GSH & 添加 $\underset{(\mu \mathrm{g})}{\mathrm{G}} \mathrm{GSH}$ & 総 GSH & $\begin{array}{c}\text { 榾出量 } \\
(\mu \mathrm{g})\end{array}$ & 检出索 \\
\hline 牛 乳 & 0 & 1600 & 1600 & 1603 & 100.2 \\
\hline 生眀当 (5 & 0 & 1600 & 1600 & 1622 & 101. \\
\hline
\end{tabular}

\begin{tabular}{|c|c|c|}
\hline 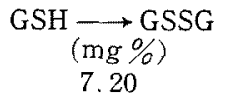 & $\begin{array}{c}\mathrm{Zn} \text { 還元後の } \mathrm{GSH} \\
(\mathrm{mg} \%) \\
7.16\end{array}$ & $\begin{array}{l}\text { 模出率 }(\%) \\
9950\end{array}$ \\
\hline
\end{tabular}

\begin{tabular}{|c|c|c|c|c|c|}
\hline 試料の䅜糆 & $\begin{array}{c}\text { 供試液中の } \\
\operatorname{GSSG}(\mu \mathrm{g})\end{array}$ & 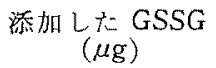 & $\begin{array}{c}\text { 総 GSSG } \\
(\mu \mathrm{g})\end{array}$ & $\begin{array}{c}\text { 検出量 } \\
(\mu \mathrm{g})\end{array}$ & $\begin{array}{c}\text { 柃出率 } \\
(\%)\end{array}$ \\
\hline$(5 \mathrm{ml})$ & 0 & 425 & 425 & 430 & 101.10 \\
\hline 牛 乳 $(5 \mathrm{ml})$ & 30 & 425 & 455 & 450 & 98.90 \\
\hline 生期白 $(5 \mathrm{~g})$ & 345 & 1080 & 1425 & 1425 & 100.00 \\
\hline
\end{tabular}

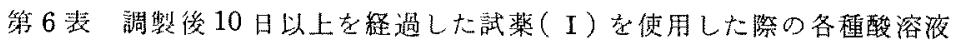
に溶解した GSH の透過率 (\%) $(540 \mathrm{m \mu}, 1 \mathrm{~cm}$ cell)

GSH のモル数 $1 \times 10^{-4} \quad 2 \times 10^{-4} \quad 3 \times 10^{-4} \quad 4 \times 10^{-4} \quad 5 \times 10^{-4} \quad 6 \times 10^{-4}$ $\begin{array}{lllllll}\text { GSH (2\% 谈酸) } & 66.50 & 44.50 & 39.25 & 23.25 & 22.75 & 22.75\end{array}$

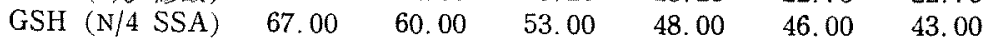
GSH $\left(10^{-2} \mathrm{~N} \mathrm{HCl}\right) \quad 71.00 \quad 58.00 \quad 50.00 \quad 46.00 \quad 44.50 \quad 44.50$

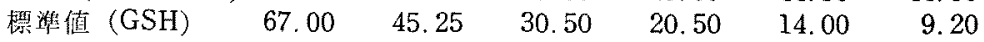

2）呈色の安定性本法に 於けるアゾ色素による呈色は極 めて安定であるとい5が，予の 観察した SSA, TCA, 葆酸溶液 等に於いても極めて安定で，24 時間経過後に於て検したものる 全く変化がなかった。これに反 しメタ燐酸溶液に於ては呈色は 非常に不安定で，使用に䩂点な い事䘮知った（第 2 表）。

3）牛乳，生莭白に添加した 既知量 GSH, GSSG の検出 GSH $4.0 \mathrm{mg}$ 蒸溞水 $25 \mathrm{ml}$ に 溶解し，ピペットにて $10 \mathrm{ml}$

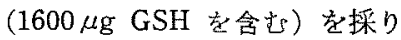
牛乳 $5 \mathrm{ml}$ 㕛は生卵户 $5 \mathrm{~g}$ を混 合し，等量の N/2 SSA と共に 乳鍊中に擂䂗した後凡てを50 $\mathrm{ml}$ 定容, 終濃度 N/4 SSA とな す。これより $1 \mathrm{ml}$ 宛を採り本 法により比色定量し，次の第 3 表の結果を得た。

次に GSH $7.2 \mathrm{mg} \%$ の水溶 液（pH 7.6）火水飽和せしめた 空気を通じて，最早ニトロプル シド反広を呈せざる至らしめ て凡てを GSSG としたものを N/4 SSA 濃度となし， Zn 末を 以て常法 ${ }^{(3)}$ の如く20 分間煮沸 還元後定容となし，此色定量し たるにGSSGをして $99.50 \%$

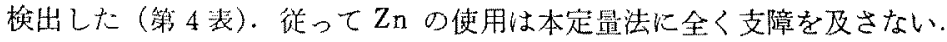

依て次の第 5 表に示したよ 5 に既知量の GSSG を含む水溶液 $5 \mathrm{ml}$ を操り，牛乳 $5 \mathrm{ml}$ 又は生畉白 $5 \mathrm{~g}$ と涺 合し，N/2 SSA $10 \mathrm{ml}$ を加えて除蛋白後 N/4 SSA にて定容となし得た濾液を Zn 末にて 20 分間惹滞還元後比 色定量したるに殆ど完全に検出定聂坛られた。 
第 7 表 ラッテ葴器のグルタチオン含有量

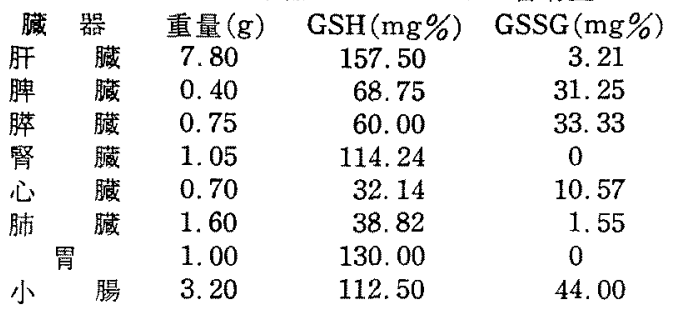

第 8 表 植物組織のグルダォン含有量 植 物 組 織 供試重量 GSH GSSG ( $(\mathrm{g}) \quad(\mathrm{mg} \%) \quad(\mathrm{mg} \%)$ しょうが(皮党除く) $\quad 4.50 \quad 11.11 \quad 2.78$ 日本权导(緑色部) $\quad 4.66 \quad 13.39 \quad 18.75$ 古菜(葉唡を除〈) $\quad 4.70 \quad 27.65 \quad 4.27$ 白 菜( $" \prime) \quad 9.60 \quad 19.79 \quad 10.42$
4）原法に於て注意せらるべき事項既に述べた よ5に Saville の原法中, 試薬 (III),(IV) Kついて は注意事項を示しているが，試薬（I）に関しては必 要に応じて調製するとして山り，予は調製後 1 乃至 2 週間を経過したものを使用する時, 呈色不充分にして 不正確な結果を招来する原因となる事を知ったので， 試薬（I）は可及的新たに調製して使用する事が望ま しいと思う.次に調製後室温中に 10 日間以上を経過 したものを使用した場合に於けるGSH の各種酸溶液 に於ける透過率 $(540 \mathrm{~m} \mu)$ 劣示した(第 6 表)。即马標 準値に比政して何れあ呈色不充分なる事が判る.

5）生物組織の SSA 浸出液に於てグルタチオンを 測定した結果歷に示したよ5に本比色定量法は

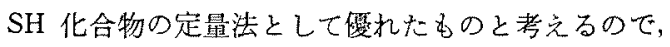

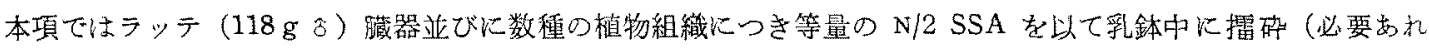
ば硅砂を加えて）除蛋白後，終濃度 $\mathrm{N} / 4 \mathrm{SSA}, 50 \mathrm{ml}$ 定容とした濾液につき $1 \mathrm{ml}$ 採り，比色定量しこれを GSH として示し，又 $20 \mathrm{ml}$ を播り少量の $\mathrm{Zn}$ 末と共に 20 分間者沸還元した後定容とした濾液より $1 \mathrm{ml}$ を採 り，比色定量しこれを GSSG として示した結果は第 7 表及び第 8 表の如くであった。

$$
\text { IV. 要 約 }
$$

$\mathrm{SH}$ 基を亜硝酸にて $\mathrm{S}$ ニトロソ㟟導体となし，これに $\mathrm{Hg}^{*}$ の存在でスルファニルアミドを反応せしめて生ず る SH と当量のジアゾニウム塩をアゾ色素として SH 化合物を比色定量する Saville の原法を生物組織の酸浸 出液に奥用す心き条件に就いて恮索した処を要約すれば次の如くなる。

（1）從来組織より SH 化合物の浸出に使用孔られた三塩素䣷酸，スルホサルチル酸，メタ燐酸，苳酸等はメ 夕烣酸除き何れる本比色定量法に确用可能である.

(2) 原法の試薬につき若干注意すべき点を指摘した.

（3）GSSG を GSH に還元する為に使用する Zn は本定量法に何等支䧊を及さない。

（4）数種の動植物組䄽のスルホサルチル酸浸出液につき本定量法を適用して澌定したる結果をGSH，GSSG として示した。

(1) B.Saville: The Analyst, 83, 670 (1958)

(2) B.Saville: ibid., 84, 188 (1959).
(3) Y. Okuda, M. Ogawa: J. Biochem., 18. 75 (1933). 